\title{
Apoptosis of osteosarcoma cultures by the combination of the cyclin-dependent kinase inhibitor SCH727965 and a heat shock protein 90 inhibitor
}

\author{
W Fu' ${ }^{1}$, SS Sharma ${ }^{1}$, L Ma ${ }^{1}$, B Chu ${ }^{1}$, MM Bui ${ }^{2,3}$, D Reed ${ }^{2,3}$ and WJ Pledger ${ }^{\star, 1,2,3}$
}

Osteosarcoma (OS) is an aggressive bone cancer typically observed in adolescents and young adults. Metastatic relapse accounts primarily for treatment failure, and obstacles to improving cure rates include a lack of efficacious agents. Our studies show apoptosis of OS cells prepared from localized and metastatic tumors by a novel drug combination: SCH727965 (SCH), a cyclin-dependent kinase inhibitor, and NVP-AUY922 (AUY) or other heat shock protein 90 inhibitor. SCH and AUY induced apoptosis when added simultaneously to cells and when AUY was added to and removed from cells before SCH addition. Sequential treatment was most effective when cells received AUY for $\sim 12 \mathrm{~h}$ and when $\mathrm{SCH}$ was presented to cells immediately after AUY removal. The apoptotic protein Bax accumulated in mitochondria of cotreated cells but was primarily cytosolic in cells receiving either agent alone. Additional data show that $\mathrm{SCH}$ and AUY cooperatively induce the apoptosis of other sarcoma cell types but not of normal osteoblasts or fibroblasts, and that $\mathrm{SCH}$ and AUY individually inhibit cell cycle progression throughout the cell cycle. We suggest that the combination of SCH and AUY may be an effective new strategy for treatment of OS.

Cell Death and Disease (2013) 4, e566; doi:10.1038/cddis.2013.101; published online 28 March 2013

Subject Category: Cancer

Osteosarcoma (OS) is the most common primary bone malignancy. It affects people of all ages, with peak incidence in adolescents and young adults. ${ }^{1}$ It occurs most commonly in the long bones of the limbs and metastasizes primarily to the lungs. The 5-year overall survival rate for patients with localized disease is $\sim 60 \%$, for patients with metastatic spread, it is less than $30 \%$; these rates have not improved significantly in the past 30 years. ${ }^{2}$ Current treatment includes complete surgical excision, which is required for a cure, and chemotherapy, most notably a combination of doxorubicin, methotrexate, and cisplatin (collectively referred to as MAP) and sometimes ifosfamide. ${ }^{1,3}$ Chemotherapy typically causes tumor necrosis; although amount of necrosis correlates with outcome, even patients with excellent necrosis face a relapse risk of $20 \%$. Thus, there is a need for new therapies for patients with metastatic and relapsed OS.

Towards this goal, we previously showed apoptosis of established OS cell lines (e.g., U2OS and SaOs-2) by the cyclin-dependent kinase (CDK) inhibitor SCH727965 (SCH) (also known as dinaciclib). ${ }^{4} \mathrm{SCH}$ inhibits the activity of CDK1, CDK2, CDK9 and CDK5.,6 CDK1 and CDK2 promote cell cycle progression, whereas CDK9 facilitates transcriptional elongation; CDK5 functions primarily in neurons. Our study also showed sensitivity, albeit modest, of newly prepared OS cell cultures to $\mathrm{SCH}$. It is possible that these cultures will respond more robustly to $\mathrm{SCH}$ in combination with other inhibitors.

Heat shock protein (Hsp) 90 is an ATP-driven molecular chaperone. ${ }^{7,8}$ It helps nascent polypeptides assume biologically active conformations, disrupts protein aggregates and repairs or removes misfolded proteins. In cancer cells, it drives oncogenesis by stabilizing labile oncoproteins and by maintaining homeostasis in hostile environments. More than 200 proteins (termed 'clients') interact with Hsp90; these include nuclear steroid receptors, transcription factors and kinases (e.g., AKT), many of which occupy central positions in biological networks. ${ }^{9} \mathrm{Hsp} 90$ is a dimer that requires ADP/ATP exchange and interaction with cochaperones for activity. ${ }^{10}$

Hsp90 inhibitors include 17-allylamino-17-demethoxygeldanamycin (AAG), ${ }^{11}$ 17-(2-dimethylaminoethyl) amino17-demethoxygeldanamycin $\quad$ (DMAG), ${ }^{12}$ NVP-HSP990 (HSP990) ${ }^{13}$ and NVP-AUY922 (AUY). ${ }^{14}$ All interact with the ATP binding site in the $\mathrm{N}$ terminus of $\mathrm{Hsp90}$ and short circuit the Hsp90 chaperone cycle; this results in the proteasome-mediated degradation of Hsp90 clients and the consequent collapse of multiple signaling pathways. ${ }^{10}$ Hsp90 inhibitors have a 100-fold greater affinity for Hsp90 in tumor cells than in normal cells and thus are selective for tumor cells. ${ }^{15}$ AAG and DMAG were the first Hsp90 inhibitors tested in clinical trials; however, both are

\footnotetext{
${ }^{1}$ Department of Molecular Oncology, Gonzmart Research Laboratory, and the Sarcoma Research Program, H. Lee Moffitt Cancer Center and Research Institute, Tampa, FL, USA; '² Department of Experimental Therapeutics, the Sarcoma Research Program, H. Lee Moffitt Cancer Center and Research Institute, Tampa, FL, USA and ${ }^{3}$ Department of Sarcoma, the Sarcoma Research Program, H. Lee Moffitt Cancer Center and Research Institute, Tampa, FL, USA

${ }^{*}$ Corresponding author: WJ Pledger, Department of Molecular Oncology, Gonzmart Research Laboratory, and the Sarcoma Research Program, H. Lee Moffitt Cancer Center and Research Institute, 12902 Magnolia Lane, Tampa, FL 33612, USA. Tel: 8139793887; Fax: 8139793893; E-mail: jack.pledger@moffitt.org Keywords: osteosarcoma; cyclin-dependent kinase; heat shock protein 90; apoptosis; SCH727965; NVP-AUY922

Abbreviations: AAG, 17-allylamino-17-demethoxygeldanamycin; AUY, NVP-AUY922; BrdU, bromodeoxyuridine; CDK, cyclin-dependent kinase; DMAG, 17-(2-dimethylaminoethyl) amino-17-demethoxygeldanamycin; FACS, fluorescence-activated cell sorting; Hsp, heat shock protein; MAP, methotrexate, cisplatin, and doxorubicin; HSP990, NVP-HSP990; PARP, poly(ADP-ribose) polymerase; PBS, phosphate-buffered saline; OS, osteosarcoma; SCH, SCH727965

Received 30.8.12; revised 12.2.13; accepted 25.2.13; Edited by M Agostini
} 
problematic due to toxicity, and AAG has poor aqueous solubility. ${ }^{16,17}$ The synthetic inhibitors HSP990 and AUY are currently in clinical trials.

In this study, we examined the effects of $\mathrm{SCH}$ and $\mathrm{Hsp90}$ inhibitors on the survival of OS cell cultures prepared by us from resected OS tumors. Drugs were added to OS cells at the same time or at separate times, and their effects on the viability of normal osteoblasts was also determined. Our results suggest that the combination of $\mathrm{SCH}$ and $\mathrm{Hsp} 90$ inhibitor may be useful for treating OS.

\section{Results}

Apoptosis of OS cells by the combination of $\mathrm{SCH}$ and Hsp90 inhibitor. OS cell cultures were prepared from four resected tumors (designated OS1001, OS1002, OS1003, OS1004) as described in Materials and Methods. OS1001 was a localized tumor in a young adult. It showed excellent necrosis (>90\%) after MAP chemotherapy, and the patient remains disease-free more than 2 years from diagnosis. OS1003 and OS1004 were primary tumors in young adult patients with widespread and non-resectable metastatic disease at presentation. OS1003 and OS1004 received MAP chemotherapy in the neoadjuvant setting with $41 \%$ and $90 \%$ necrosis, respectively; a biopsy specimen of a metastasis of OS1003 had $88 \%$ necrosis. The patients lived for 7 (OS1003) and 10 (OS1004) years from diagnosis after progressing though adjuvant MAP and additional chemotherapies. OS1002 was a previously treated, recurrent metastatic tumor without systemic therapy after recurrence; the patient has been lost to follow-up.

All four OS cultures expressed osteoblastic markers (osteopontin, osteocalcin and alkaline phosphatase) as determined by RT-PCR (Figure 1a). Normal human

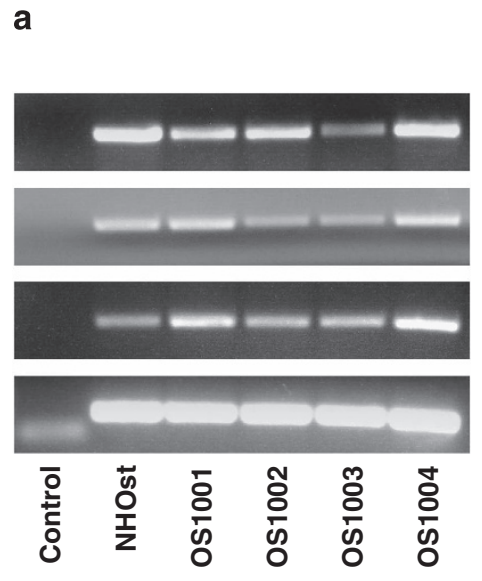

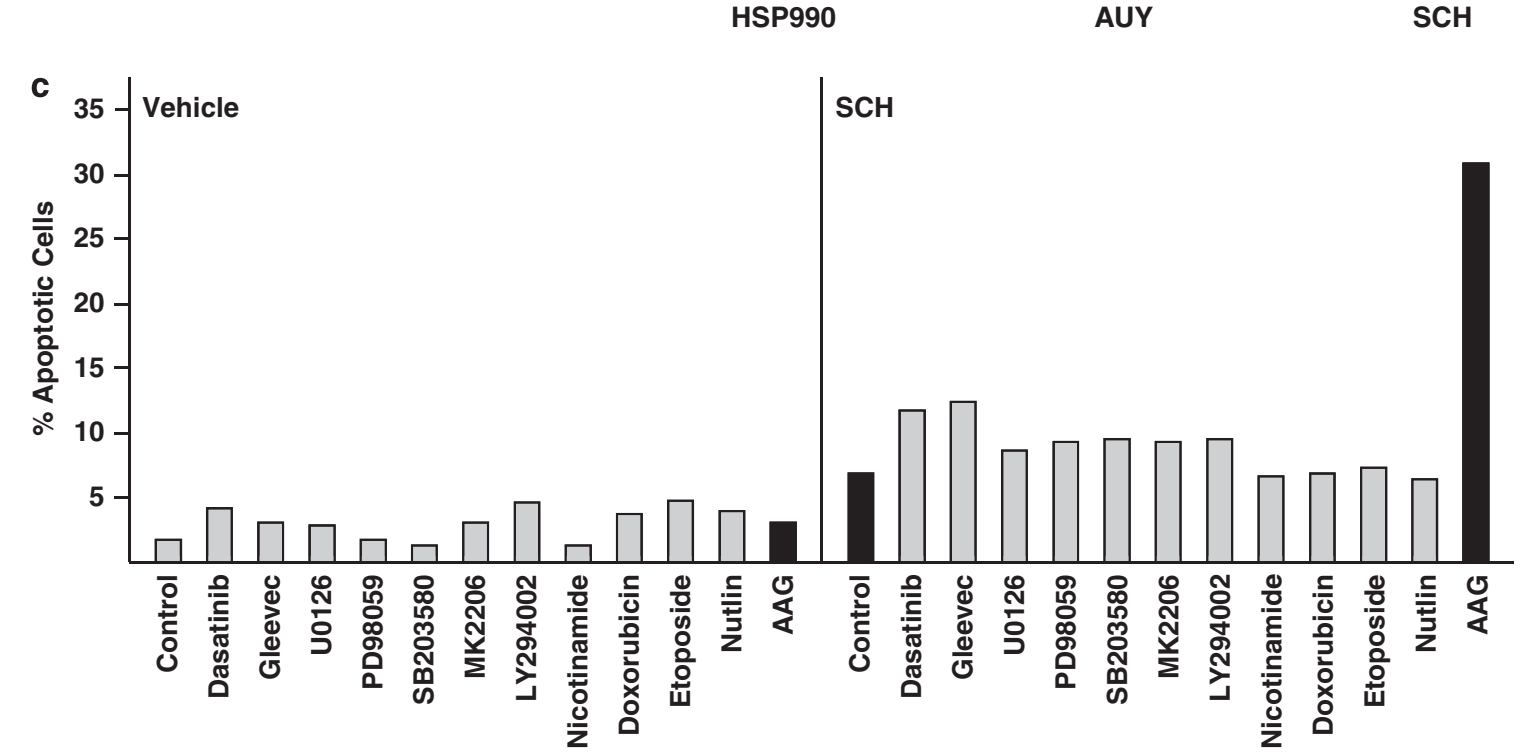

b

Alkaline

Phosphatase

Osteopontin

Osteocalcin

GAPDH

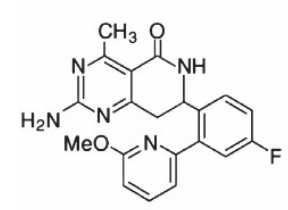

HSP990

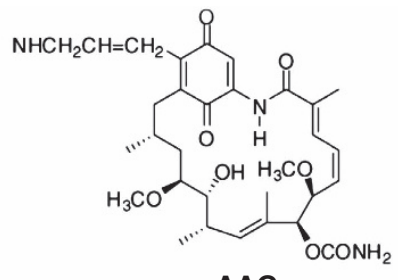

AAG

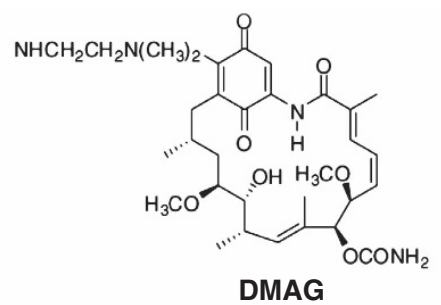

DMAG<smiles>CCNC(=O)c1noc(-c2cc(C(C)C)c(O)cc2O)c1-c1ccc(CN2CCOCC2)cc1</smiles>

AUY<smiles>CCc1cnn2c(NCc3ccc[n+](C)c3)cc(N3CCCC[C@H]3CCO)nc12</smiles>

$\mathrm{SCH}$

Figure 1 Cell lines and inhibitors. (a) RT-PCR was performed on CDNA derived from the indicated cell lines using probes for alkaline phosphatase, osteopontin, osteocalcin and GAPDH (loading control). NHOst cells are normal human osteoblasts and are included as a positive control. Control (lane 1) has no cDNA. (b) Structures of the inhibitors used in this study. (c) OS1002 cells received $10 \mathrm{~nm} \mathrm{SCH}$ and the indicated inhibitors for $72 \mathrm{~h}$. Percent apoptotic cells was determined by FACS analysis of annexin V-stained cells. Concentrations of inhibitors used were: MK2206 (1 $\mu \mathrm{M})$; Gleevec $(10 \mu \mathrm{M})$; etoposide (1 $\mu \mathrm{M})$; doxorubicin (250 nM); dasatinib (100 nM); LY294002 (20 $\mu \mathrm{M})$;

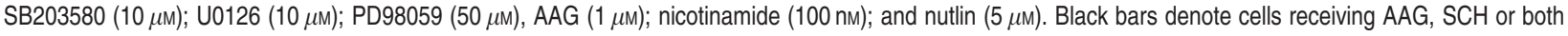


osteoblasts (NHOst) are shown as a positive control. The structures of $\mathrm{SCH}$ and of the Hsp90 inhibitors used in our study are diagramed in Figure $1 \mathrm{~b}$

We previously showed that newly prepared OS cultures apoptose weakly when exposed to $\mathrm{SCH}$ alone for $72-96 \mathrm{~h}^{4}$ To potentially improve this response, we cotreated OS1002 cells with $10 \mathrm{~nm} \mathrm{SCH}$ and inhibitors of tyrosine kinases (dasatinib, Gleevec), mitogen-activated protein kinases (U0126, PD98059, SB203580), AKT signaling (MK2206, LY294002), class III histone deacetylases (nicotinamide), DNA synthesis (doxorubicin, etoposide), p53 (nutlin) or Hsp90 (AAG) for $72 \mathrm{~h}$. Apoptosis was monitored by FACS (fluorescence-activated cell sorting) analysis of annexin V-stained cells; annexin $\mathrm{V}$ detects externalized phosphatidylserines, a marker of early apoptosis. ${ }^{18}$ None of the agents tested induced apoptosis in the absence of $\mathrm{SCH}$, and only AAG increased responsiveness to $\mathrm{SCH}$ (Figure 1c). AAG by itself had little effect if any. Thus, Hsp90 inhibitors represent a means of sensitizing OS cells to $\mathrm{SCH}$ (or vice versa).

a

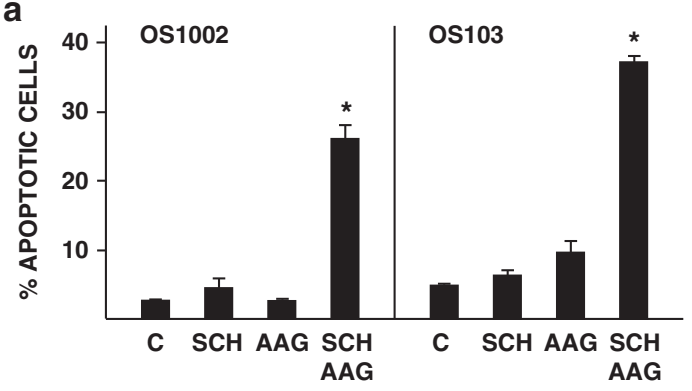

C

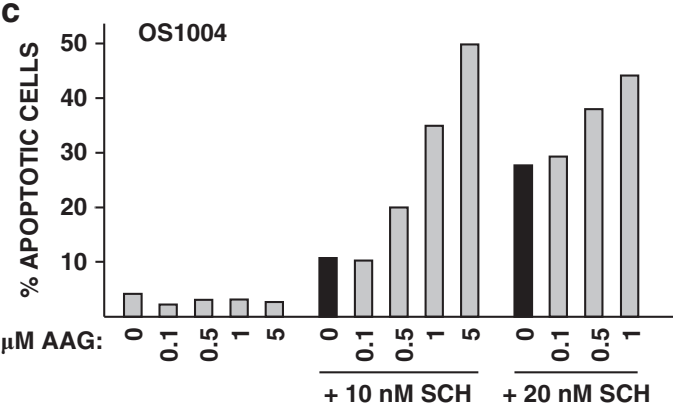

e

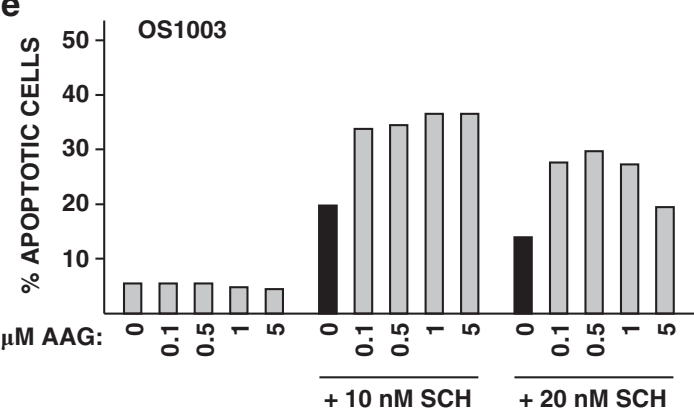

The apoptotic response of OS cells to SCH plus AAG was highly signficant (Figure 2a) and was seen in all four OS cell lines (Figure $2 \mathrm{~b}$ ). Percentages of cells undergoing apoptosis were generally less than $10 \%$ for AAG, less than $20 \%$ for $\mathrm{SCH}$, and more than $30 \%$ and as high as $50 \%$ for $\mathrm{SCH}$ plus AAG. Concentrations of AAG eliciting maximal responses in combination with $\mathrm{SCH}$ ranged from $0.1 \mu \mathrm{m}$ to $5 \mu \mathrm{m}$ (Figures $2 \mathrm{~b}-\mathrm{e}$ ). DMAG (500 nm) also induced apoptosis when added to cells with SCH (Figure 1f). Some cotreated cells were both annexin $\mathrm{V}$-positive and propidium iodide-positive, which is indicative of late apoptosis ('secondary necrosis') or of necrotic, non-apoptotic cell death (Supplementary Figures 1a-d). ${ }^{19}$

Two additional Hsp90 inhibitors were tested: HSP990 and AUY. In combination with $\mathrm{SCH}$, both inhibitors induced apoptosis of OS cells as effectively as did AAG and DMAG but at much lower concentrations (50 nm) (Figures $3 a-c)$. As additional methods of monitoring apoptosis, we show caspase-3 activation (Figure $3 d$ ) and PARP (poly(ADP-ribose)

b

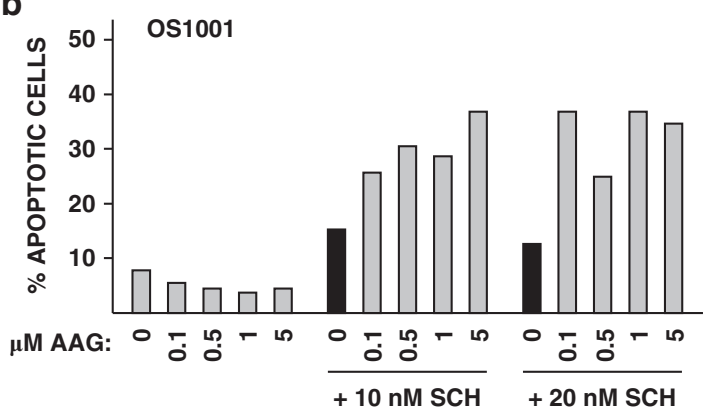

d

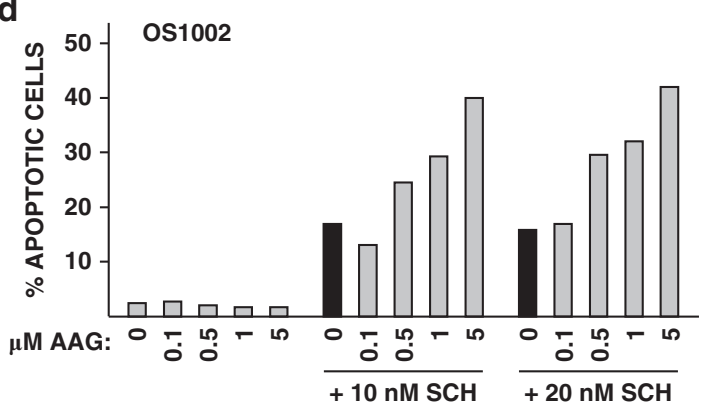

$\mathbf{f}$

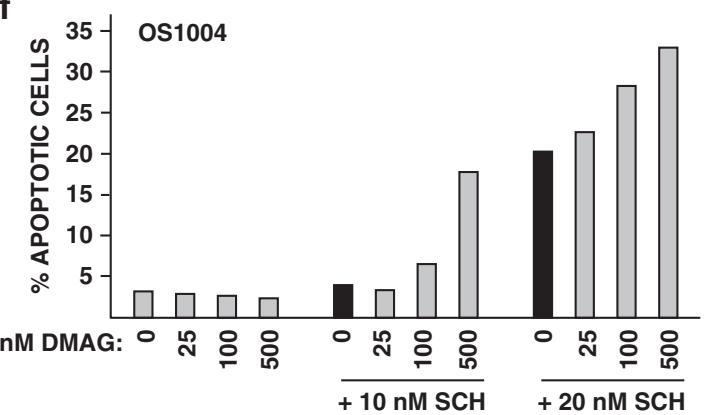

Figure 2 Apoptosis of OS cells cotreated with SCH and AAG. (a) OS1002 and OS1003 cells received $10 \mathrm{~nm} \mathrm{SCH,} 5 \mathrm{~mm}$ AAG, or both for $48 \mathrm{~h}$. Error bars indicate S.D. Asterisk indicates significant $P$-value. $P$-values for OS1002 cells are: SCH, 0.15; AAG, 0.59; both, 0.0019. $P$-values for OS1003 cells are: SCH, 0.14; AAG, 0.05 ; both, 0.0003. C: control. (b-e) Cells received the indicated concentrations of SCH and AAG for $48 \mathrm{~h}$. Black bars denote cells receiving SCH alone. (f) OS1004 cells received the indicated concentrations of SCH and DMAG for $48 \mathrm{~h}$. Black bars denote cells receiving SCH alone. (a-f) Percent apoptotic cells was determined by FACS analysis of annexin V-stained cells 

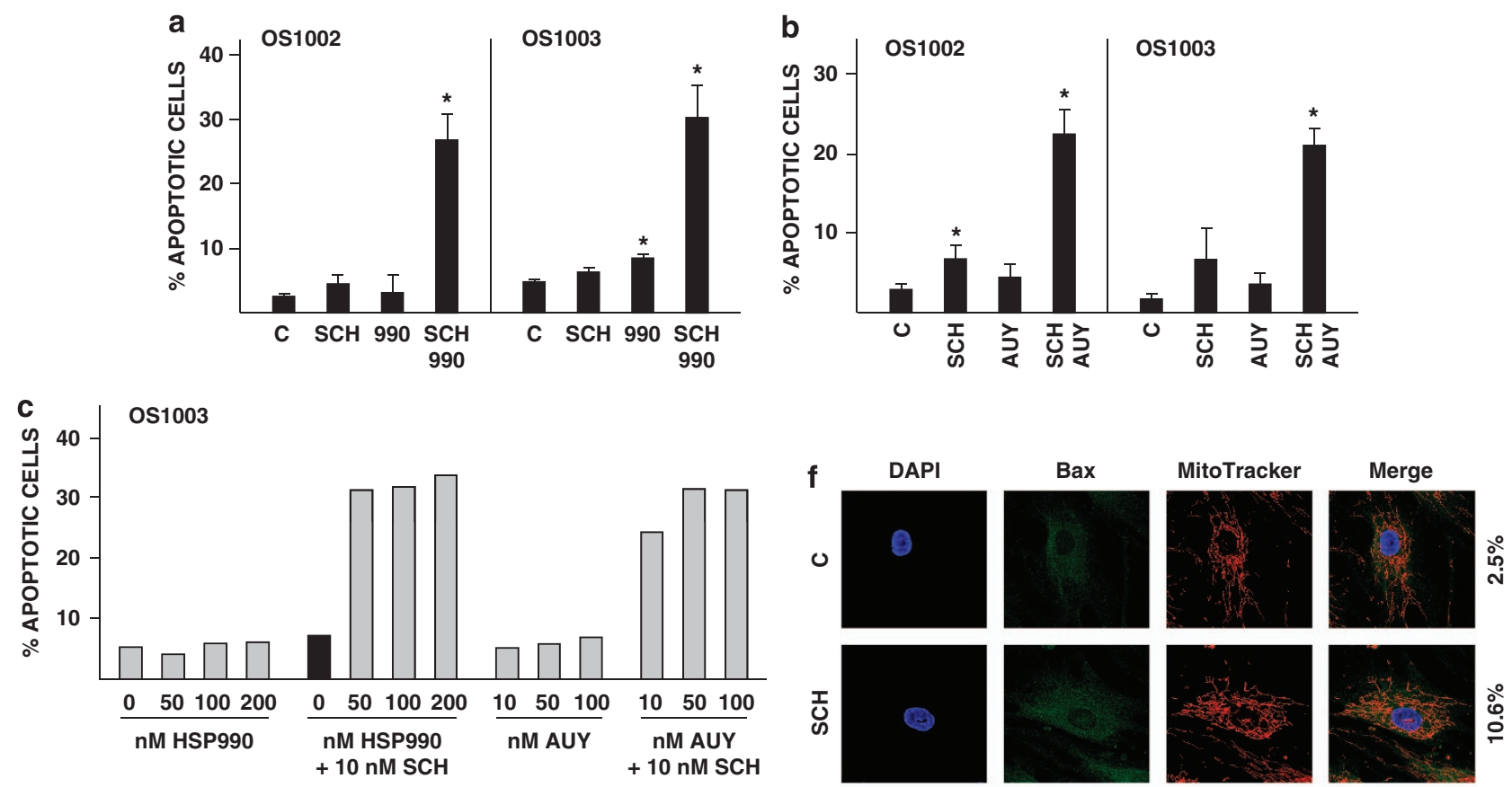

d
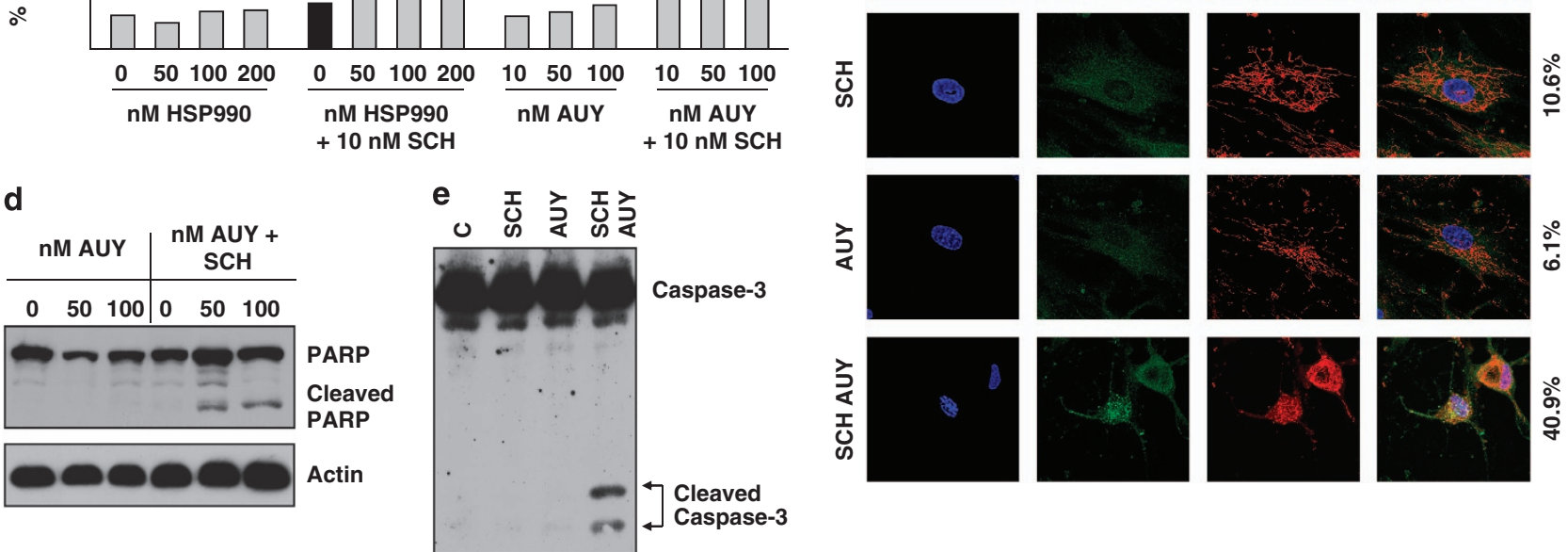

Figure 3 Caspase-3 activation and Bax translocation in OS cells cotreated with SCH and AUY. (a) OS1002 and OS1003 cells received $10 \mathrm{~nm} \mathrm{SCH,} 100 \mathrm{HSP} 990$ (990), or both for $48 \mathrm{~h}$. Error bars indicate S.D. Asterisk indicates significant $P$-value. $P$-values for OS1002 cells are: SCH, $0.15 ; 990,0.23 ;$ both, 0.007 . $P$-values for OS1003 cells are: $\mathrm{SCH}, 0.14 ; 990,0.01$; both, 0.01 . C: control. (b) OS1002 and OS1003 cells received $10 \mathrm{~nm} \mathrm{SCH}$ and $100 \mathrm{~nm} \mathrm{AUY} \mathrm{or} \mathrm{both} \mathrm{for} 48 \mathrm{~h}$. Error bars indicate S.D. Asterisk indicates significant $P$-value. $P$-values for OS1002 cells are: SCH, 0.008 ; AUY, 0.05 ; both, 0.001 . $P$-values for OS1003 cells are: SCH, $0.22 ;$ AUY, 0.09 ; both, 0.0002 . C: control. (c) OS cells received the indicated concentrations of inhibitors for $48 \mathrm{~h}$. (a-c) Percent apoptotic cells was determined by FACS analysis of annexin V-stained cells. Black bars denote cells receiving SCH (d) OS1002 cells received $10 \mathrm{~nm} \mathrm{SCH}$ and 50 or $100 \mathrm{~nm} \mathrm{AUY} \mathrm{for} 48 \mathrm{~h}$. Cell extracts were western blotted with antibody to PARP or actin (Ioading control). (e) OS1002 cells received $10 \mathrm{~nm} \mathrm{SCH}$ and $100 \mathrm{~nm}$ AUY for $24 \mathrm{~h}$. Cell extracts were western blotted with antibody to caspase-3. C: control. (f) OS1003 cells received $10 \mathrm{~nm}$ SCH and $100 \mathrm{~nm}$ AUY for $48 \mathrm{~h}$. Cells were co-stained with anti-Bax antibody (green), MitoTracker Red (red), and the nuclear marker DAPI (blue) as described in Materials and Methods. Magnification is $\times 1890$. Numbers to the right of the photographs indicate the percentage of cells with mitochondrial-localized Bax. C: control

polymerase) cleavage (Figure 3e) in OS1002 cells cotreated with SCH and AUY. Caspases become active when cleaved and disrupt cell function to elicit cell death; PARP is a caspase-3 substrate. ${ }^{20} \mathrm{Bax}$, a member of the $\mathrm{Bcl}-2$ family of apoptosis regulatory proteins, perforates the outer mitochondrial membrane to release cytochrome $\mathrm{c}$, which indirectly activates caspase- $3 .{ }^{21}$ Bax is cytosolic in healthy cells and translocates to mitochondria in response to apoptotic signals. We show that Bax accumulates in mitochondria of OS1003 cells cotreated with $\mathrm{SCH}$ and AUY as evidenced by its colocalization with the mitochrondrial dye MitoTracker (Figure 3f). Colocalization was observed in $40.9 \%$ of cotreated cells as compared with $2.5 \%, 10.6 \%$ and $6.1 \%$ of control, $\mathrm{SCH}$-treated and AUY-treated cells, respectively. Together, the data in Figures 2 and 3 show that $\mathrm{SCH}$ and Hsp90 inhibitors collaboratively induce robust apoptosis of OS cells.
Hsp90 inhibitors also boosted the apoptosis of OS cells cotreated with roscovitine $(20 \mu \mathrm{m})$ or flavopiridol (200 nм) (Supplementary Figures $2 \mathrm{a}$ and $\mathrm{b}$ ). These agents inactivate CDKs 1, 2 and 9, as does $\mathrm{SCH}$; roscovitine also inactivates CDK7, and flavopiridol is a pan-CDK inhibitor (CDKs 1, 2, 4, 6, 7 and 9). ${ }^{22-25} \mathrm{Hsp} 90$ inhibitors did not induce apoptosis when combined with PD0332991, which selectively targets CDK4 and CDK6 (Supplementary Figure 2c). ${ }^{26}$ This finding may be explained by redundant actions of PD0332991 and Hsp90 inhibitors: PD0332991 inactivates CDK4 and CDK6, and Hsp90 inhibitors downregulate CDK4 and CDK6. ${ }^{27,28}$

To be useful in chemotherapy, drugs must selectively kill tumor cells while sparing normal cells. Cotreatment of normal human osteoblasts (hFOB1.19) or fibroblasts (WI38) with $\mathrm{SCH}$ and AUY did not appreciably increase the percentage of annexin V-positive cells (Figures 4a and b) or induce caspase 

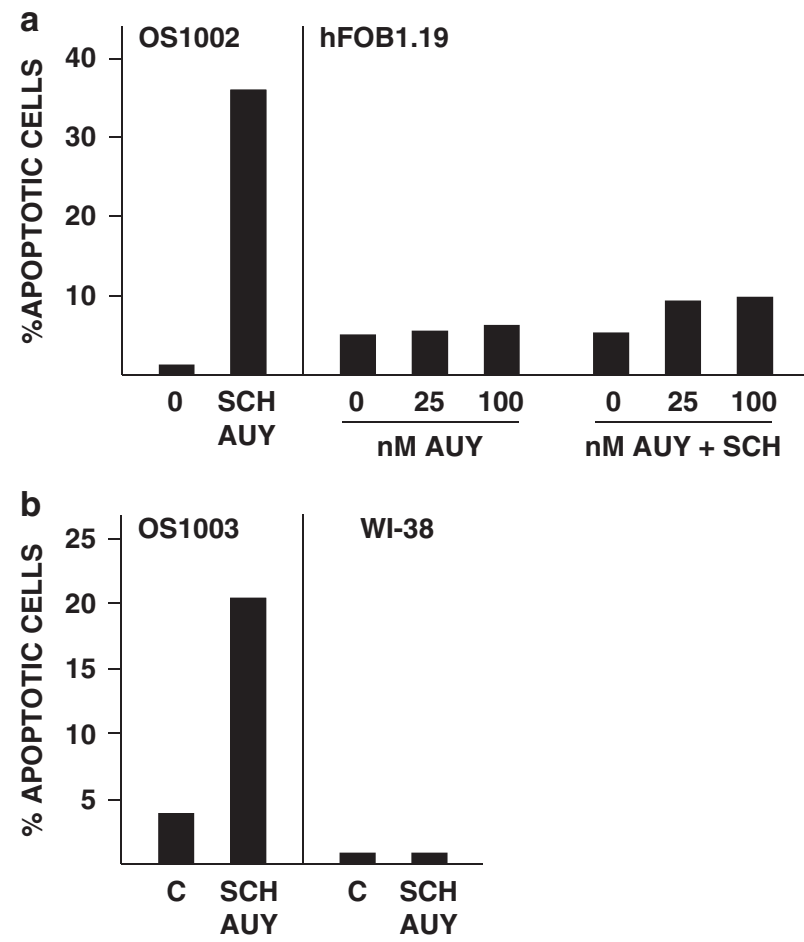

C

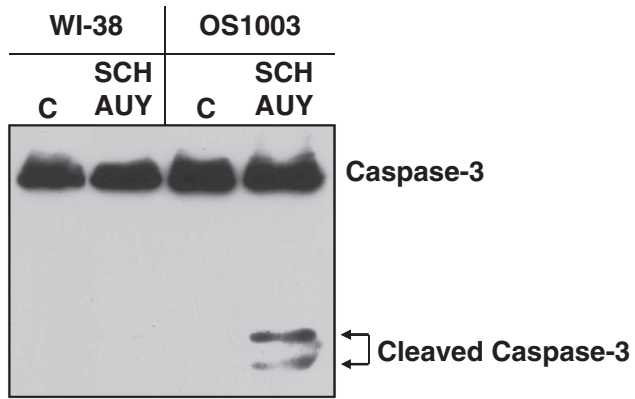

Figure 4 Survival of normal human osteoblasts and fibroblasts cotreated with $\mathrm{SCH}$ and AUY. (a) OS1002 and hFOB1.19 cells received $10 \mathrm{~nm} \mathrm{SCH}$ and 25 or $100 \mathrm{~nm}$ AUY for $24 \mathrm{~h}$. Percent apoptotic cells was determined by FACS analysis of annexin V-stained cells. (b, c) OS1003 and WI38 cells received $10 \mathrm{~nm} \mathrm{SCH}$ and $100 \mathrm{~nm}$ AUY for $24 \mathrm{~h}$. Percent apoptotic cells was determined by FACS analysis of annexin V-stained cells (b). Caspase-3 cleavage were determined by western blotting of cell extracts with antibody to caspase-3 (c). C: control

cleavage (Figure 4c). In contrast, 20 to $30 \%$ of cotreated OS cells were annexin V-positive (Figures $4 \mathrm{a}$ and b) and caspase cleavage was readily apparent (Figure 4c). Thus, the combination of $\mathrm{SCH}$ and $\mathrm{AUY}$ preferentially targets tumor cells rather than normal cells.

SCH induces apoptosis of OS cells previously exposed to AUY. We asked whether AUY and SCH induce apoptosis when added sequentially rather than simultaneously to cells. OS1002 cells received one inhibitor for $12 \mathrm{~h}$, were refed with fresh medium containing the second inhibitor, and were harvested $36 \mathrm{~h}$ after refeeding. Cells did not apoptose when exposed to $\mathrm{SCH}$ and then to AUY (Figure 5a). They did, however, apoptose when the opposite was done: AUY followed by $\mathrm{SCH}$ was as effective as AUY and $\mathrm{SCH}$ together ( $\sim 27 \%$ apoptotic cells in both conditions).

AUY was maximally effective when applied to cells for $12 \mathrm{~h}$ but only marginally effective when applied to cells for $6 \mathrm{~h}$ (Figure 5b). Effectiveness also depended on the timing of $\mathrm{SCH}$ addition relative to AUY removal. In the experiment shown in Figure 5c, OS1002 cells received AUY for $18 \mathrm{~h}$ and were incubated in fresh medium for 0,1 or $4 \mathrm{~h}$ before addition of $\mathrm{SCH}$; cells were harvested $48 \mathrm{~h}$ after $\mathrm{SCH}$ addition. When $\mathrm{SCH}$ was added to cells immediately after AUY removal, $30 \%$ of the cells apoptosed. Delaying $\mathrm{SCH}$ addition for $1 \mathrm{~h}$ reduced the percentage of apoptotic cells to $17 \%$; delaying $\mathrm{SCH}$ addition for $4 \mathrm{~h}$ reduced it to $13 \%$. Thus, sequential addition of $\mathrm{AUY}$ and $\mathrm{SCH}$ to OS cells is most effective when there is no gap between treatments.

Responsiveness of AUY-pretreated cells to SCH did not reflect the presence of residual AUY. AUY substantially reduced the phosphorylation (and thus the activity) of the Hsp90 client AKT; when AUY was withdrawn, phospho-AKT reaccumulated to near starting levels within $1 \mathrm{~h}$ (Figure $5 \mathrm{~d}$ ). Total amounts of AKT did not appreciably decline in cells receiving AUY for times up to $24 \mathrm{~h}$; loss of AKT activity in the absence of changes in AKT abundance has also been observed in other systems. ${ }^{29}$

SCH and AUY inhibit cell cycle progression. OS cells begin apoptosing within $12 \mathrm{~h}$ of addition of SCH plus AUY (Figure 6a). We performed a cell cycle analysis to determine whether cells are cycling or arrested at this time. First, we quantified DNA content by propidium iodide staining. OS1002 cells received SCH, AUY or both for $12,15,18$ or $22 \mathrm{~h}$. Cell cycle distributions were the same for all three treatments and at all time points (Figure 6b). On average, percentages of drug-treated cells in G0/G1, S and G2/M were $65 \%, 25 \%$ and $13 \%$, respectively. In comparison, percentages of control cells in G0/G1, S and G2/M were $52 \%, 35 \%$ and $15 \%$, respectively. The small decrease in percentage of cells in S phase and accompanying increase in percentage of cells in G0/G1 in drug-treated as compared with control cultures suggest that $\mathrm{SCH}$ and $\mathrm{AUY}$, alone and together, modestly inhibit $S$ phase entry. We note that cells were attached to the plates at all time points.

Second, as part of the same experiment, we monitored DNA synthesis by bromodeoxyuridine (BrdU) incorporation. Cells received BrdU $12 \mathrm{~h}$ after drug addition and were harvested 3,6 and $10 \mathrm{~h}$ later (these time points correspond to the 15, 18 and $22 \mathrm{~h}$ time points in Figure $6 \mathrm{~b}$ ). The percentage of control cells incorporating BrdU increased progressively from $28 \%$ at $3 \mathrm{~h}$ to $45 \%$ at $10 \mathrm{~h}$ (Figure $6 \mathrm{c}$ ). In contrast, the BrdU-labeled component of $\mathrm{SCH}$-treated, AUY-treated, and co-treated populations remained constant. Whereas 22-29\% of drug-treated cells were in S phase as detected by propidium iodide (Figure 6b), only $9-12 \%$ of the drug-treated cells were BrdU-labeled (Figure $6 \mathrm{c}$ ). These data suggest that cells do not actively synthesize DNA in the presence of $\mathrm{SCH}$, AUY or both. Cotreatment of cells with $\mathrm{SCH}$ and $\mathrm{AUY}$ for $12 \mathrm{~h}$ did not induce histone H2AX phosphorylation (Supplementary Figure 3), a marker of double-stranded DNA breakage, ${ }^{30}$ and thus does not cause DNA damage. 

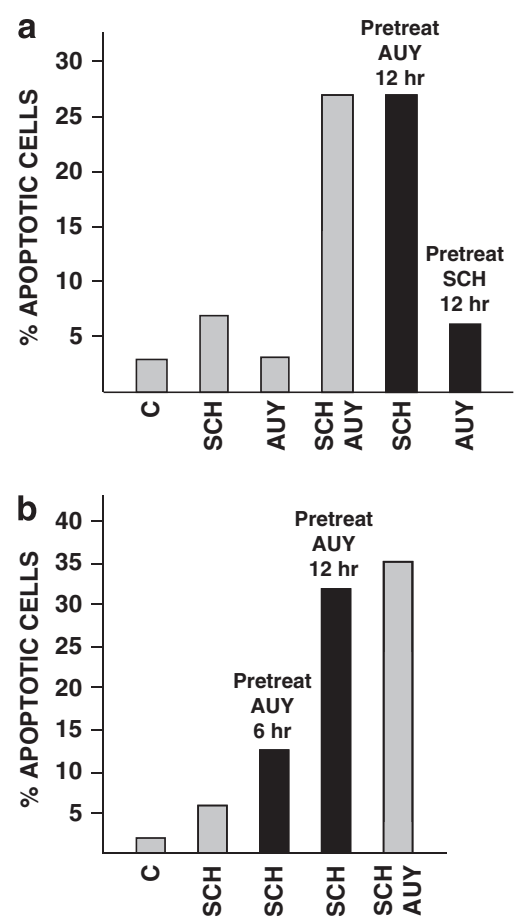
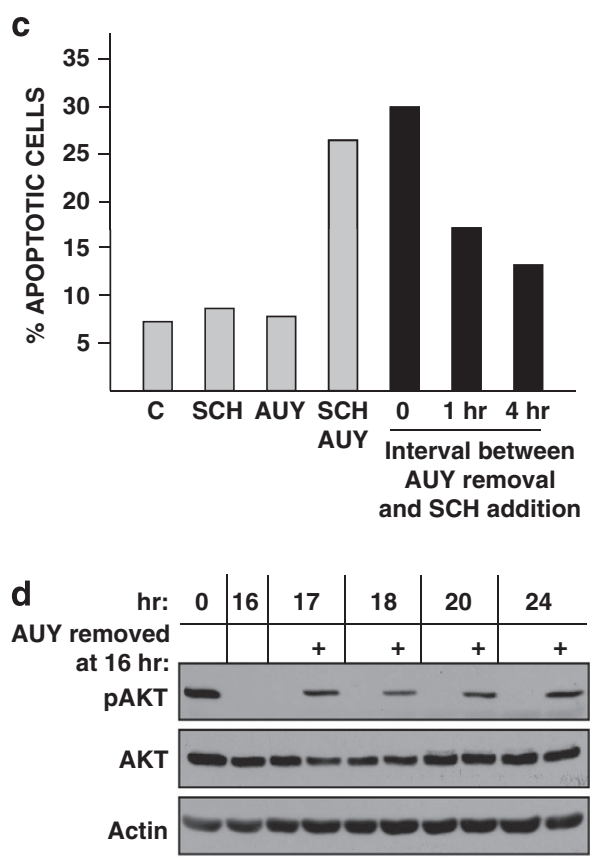

Figure 5 Sequential addition of AUY and SCH to OS cells. (a) OS1002 cells received $100 \mathrm{~nm} \mathrm{AUY} \mathrm{or} 10 \mathrm{~nm} \mathrm{SCH} \mathrm{for} 12 \mathrm{~h}$ (black bars). Untreated (gray bars) and pretreated cells were refed with fresh medium containing SCH, AUY or both and were harvested $36 \mathrm{~h}$ after refeeding. (b) OS1002 cells received $100 \mathrm{~nm}$ AUY for 6 or $12 \mathrm{~h}$ (black bars). Untreated (gray bars) and pretreated cells were refed with fresh medium containing SCH (10 nM) or SCH plus AUY and were harvested $36 \mathrm{~h}$ after refeeding. (c) Gray bars: OS1002 cells were refed with medium containing $10 \mathrm{~nm} \mathrm{SCH,} 100 \mathrm{~nm} \mathrm{AUY} \mathrm{or} \mathrm{both} \mathrm{and} \mathrm{were} \mathrm{harvested} 48 \mathrm{~h}$ later. Black bars: OS1002 cells pretreated with AUY for $18 \mathrm{~h}$ were refed with fresh medium containing SCH or were incubated in medium alone for 1 or $4 \mathrm{~h}$ before addition of SCH. Cells were harvested $48 \mathrm{~h}$ after SCH addition. (a-c) Percent apoptotic cells was determined by FACS analysis of annexin V-stained cells. C: control. (d) OS1002 cells received $100 \mathrm{~nm}$ AUY for $16 \mathrm{~h}$. Cells were refed with fresh medium with $(+)$ or without AUY and were harvested at the indicated times. Amounts of AKT, phospho-AKT (pAKT) and actin (loading control) were determined by western blotting

Impaired S phase progression was not accompanied by a decrease in the percentage of G2/M cells (Figure 6b); this indicates that drug-treated cells do not exit G2/M. As further evidence, BrdU-positive cells accumulated in G0/G1 $10 \mathrm{~h}$ after BrdU addition to control but not drug-treated cultures (Figure 6d). Collectively, our data suggest that $\mathrm{SCH}$ and AUY 'freeze' cells in multiple phases of the cell cycle. We conclude that OS cells cotreated with SCH and AUY are not cycling at the onset of apoptosis. Cell cycle arrest, however, is insufficient or unrelated to apoptosis: cell cycle arrest occurs in response to either $\mathrm{SCH}$ or $\mathrm{AUY}$, whereas efficient apoptosis requires both $\mathrm{SCH}$ and $\mathrm{AUY}$.

Combinatorial actions of $\mathrm{SCH}$ and AAG on other sarcoma cell cultures. We tested the effects of $\mathrm{SCH}$ and AAG on additional cultures prepared by us from resected sarcoma tissue: a low-grade myxofibrosarcoma (Figure 7a), a high-grade pleomorphic sarcoma with lung metastasis (Figure $7 \mathrm{~b}$ ) and a high-grade dedifferentiated liposarcoma (Figure 7c). All were refractory to AAG alone and more sensitive to $\mathrm{SCH}$ in the presence than in the absence of AAG. Myxofibrosarcoma cells were especially responsive to $\mathrm{SCH}$ plus AUY: more than $50 \%$ of cells apoptosed within a 40-hr treatment period. These findings extend the apoptotic actions of $\mathrm{SCH}$ and Hsp90 inhibitors to at least some other sarcomas in addition to OS.

\section{Discussion}

Our studies show apoptosis of OS cultures by a novel drug combination: the $\mathrm{CDK}$ inhibitor $\mathrm{SCH}$ and an Hsp90 inhibitor. CDKs drive the cell cycle, which is often dysregulated in cancer, and ensure an ample supply of short-lived antiapoptotic proteins. Hsp90 is essential for the proper functioning of numerous proteins and signal transduction pathways and is more susceptible to Hsp90 inhibitors in tumor cells than in normal cells. Thus, CDKs and Hsp90 are rational targets for drug intervention.

The OS cultures used in our experiments were derived from resected tumors and were passaged less than 20 times. Gillet et al. ${ }^{31}$ suggest that long-term culturing radically alters gene expression and distorts drug sensitivity: they found striking differences in the multi-drug resistance gene profiles of ovarian clinical samples versus established ovarian cancer cell lines. Thus, use of OS cultures minimizes potential culture-induced anomalies and increases the likelihood of obtaining information that will translate successfully to the clinic. We note that OS cultures are much less sensitive to $\mathrm{SCH}$ than are established OS cell lines such as U2OS and SaOs-2. ${ }^{4}$

We used four Hsp90 inhibitors in our experiments: AAG and DMAG, which are ansamycin derivatives, and HSP990 and AUY, which are synthetic small molecules classified as 
a

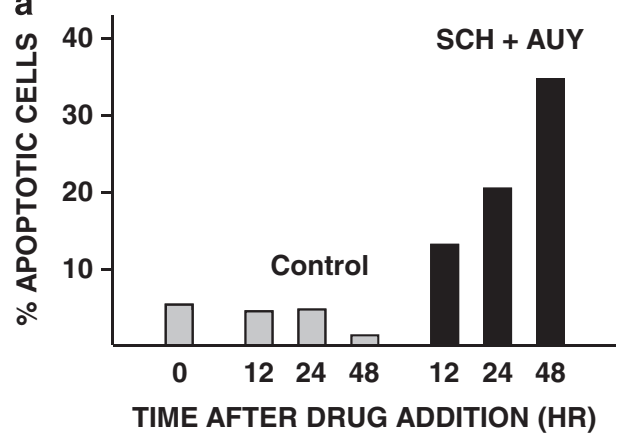

C
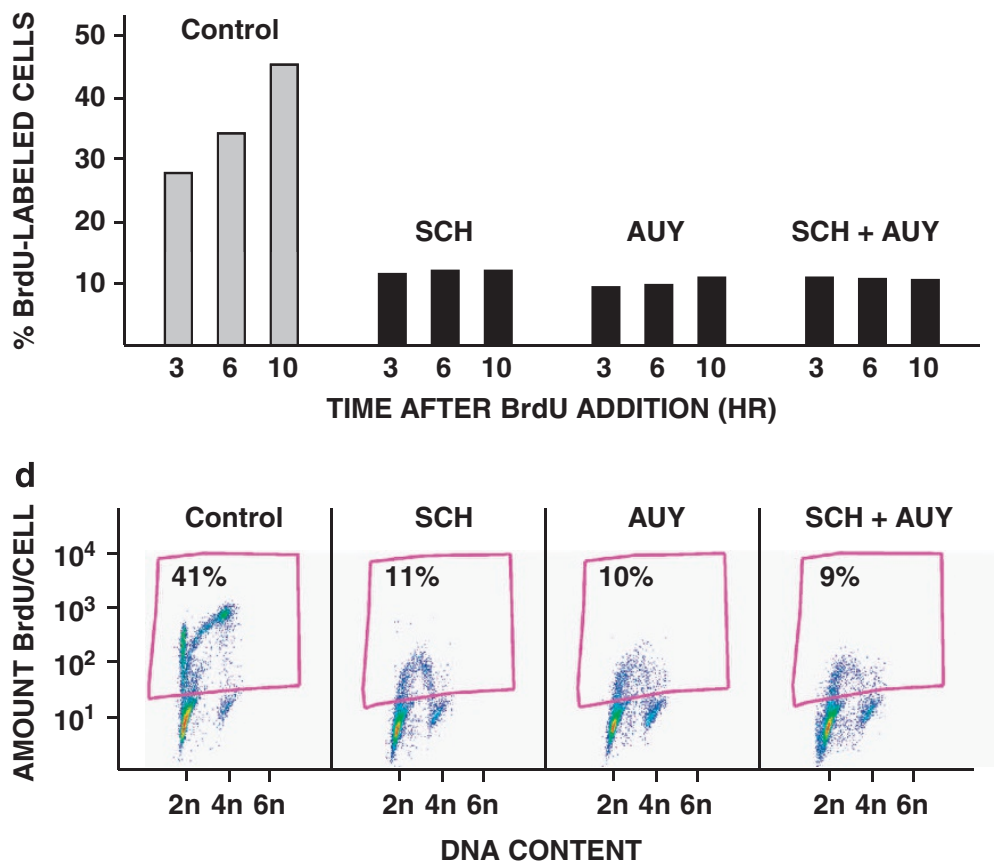

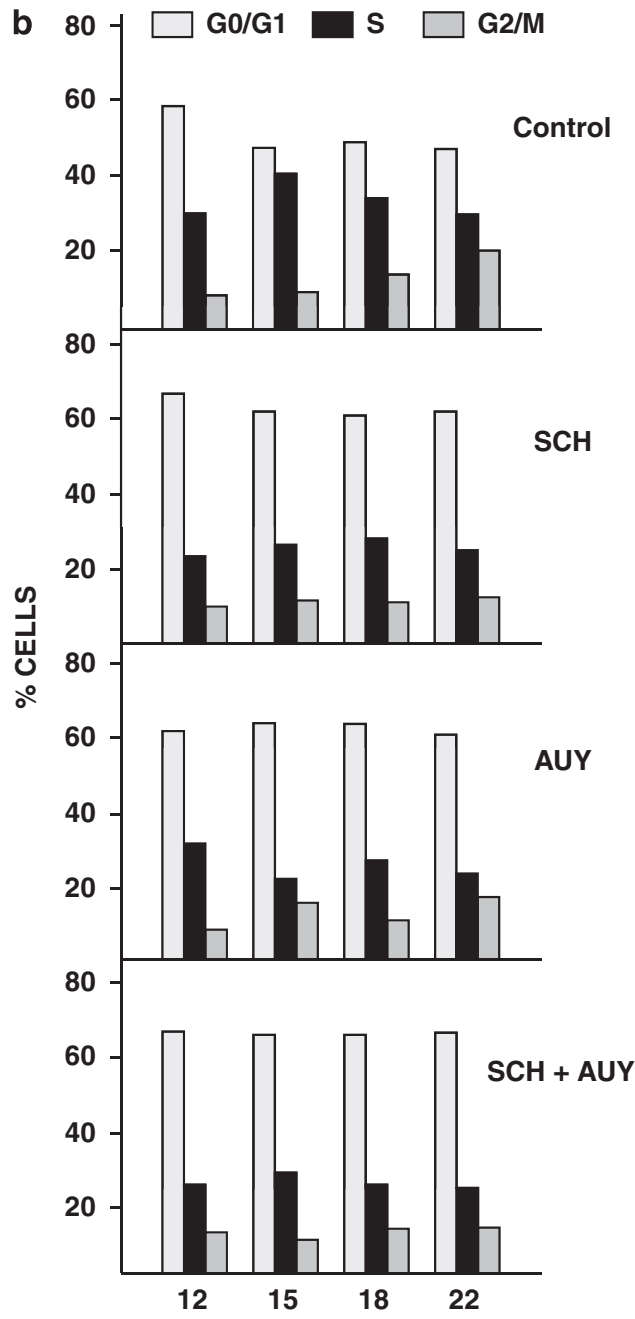

TIME AFTER DRUG ADDITION (HR)

Figure $6 \mathrm{SCH}$ and AUY inhibit cell cycle progression. (a) OS1002 cells received $20 \mathrm{~nm} \mathrm{SCH}$ and $100 \mathrm{~nm} \mathrm{AUY} \mathrm{for} \mathrm{12,} 24$ or $48 \mathrm{~h}$. Percent apoptotic cells was determined by FACS analysis of annexin V-stained cells. (b) Cells received $20 \mathrm{~nm} \mathrm{SCH,} 100 \mathrm{~nm} \mathrm{AUY,} \mathrm{or} \mathrm{both} \mathrm{for} \mathrm{12,} \mathrm{15,} 18$ or $22 \mathrm{~h}$. Cells were stained with propidium iodide, and cell cycle position was determined as described in Materials and Methods. (c) Cells received $20 \mathrm{~nm} \mathrm{SCH,} 100 \mathrm{~nm} \mathrm{AUY,} \mathrm{or} \mathrm{both} \mathrm{for} 12 \mathrm{~h}$. BrdU was added, and cells were harvested 3,6 and $10 \mathrm{~h}$ after BrdU addition. Percent BrdU-labeled nuclei was determined as described in Materials and Methods. (d) Scatter plots for the $10 \mathrm{~h}$ time point in (c) are shown. The percentages of cells in S phase are indicated

aminopyridine and resorcinol-containing, respectively. ${ }^{32}$ None induced OS apoptosis in the absence of $\mathrm{SCH}$; all enhanced the weak apoptotic response elicited by $\mathrm{SCH}$. HSP990 and AUY were especially potent, producing effects at concentrations of $25-50 \mathrm{~nm}$. OS cells apoptosed when cotreated with $\mathrm{SCH}$ and an Hsp90 inhibitor regardless of whether their tumor of origin was localized or metastatic. Of particular note, OS1002 cells were derived from a tumor that recurred after chemotherapy. Combined application of $\mathrm{SCH}$ and Hsp90 inhibitor also induced the apoptosis of other sarcoma types but did not affect the survival of normal osteoblasts.

Interestingly, we show that AUY and $\mathrm{SCH}$ need not be present together to induce OS apoptosis: AUY can be added and removed before addition of $\mathrm{SCH}$ but not vice versa. This finding suggests that AUY elicits an event (or events) that renders $\mathrm{OS}$ cells responsive to $\mathrm{SCH}$. For example, it may cause an anti-apoptotic protein to degrade or to lose its active conformation or may simply enervate cells by allowing buildup of toxic, unfolded protein aggregates. ${ }^{33}$ Sequential treatment was most effective when cells were primed with AUY for $\sim 12 \mathrm{~h}$ and immediately exposed to $\mathrm{SCH}$. Thus, the AUY-induced priming event is complete by $12 \mathrm{~h}$ and is shortlived in the absence of AUY.

As a reverse scenario, it is possible that $\mathrm{SCH}$ renders OS cells responsive to AUY. AUY may elicit both apoptotic and anti-apoptotic signals; negation of the anti-apoptotic signal by $\mathrm{SCH}$ would allow apoptosis to proceed. A potential anti-apoptotic signal is the induction of Hsp72. Hsp72 is a member of the Hsp70 family of molecular chaperones, and Hsp90 inhibitors upregulate its expression by activating the Hsf-1 transcription factor. ${ }^{34}$ Colon cancer cells depleted of Hsp72 (and a second Hsp70 isoform), apoptosed when exposed to AAG, whereas mock-depleted cells did 

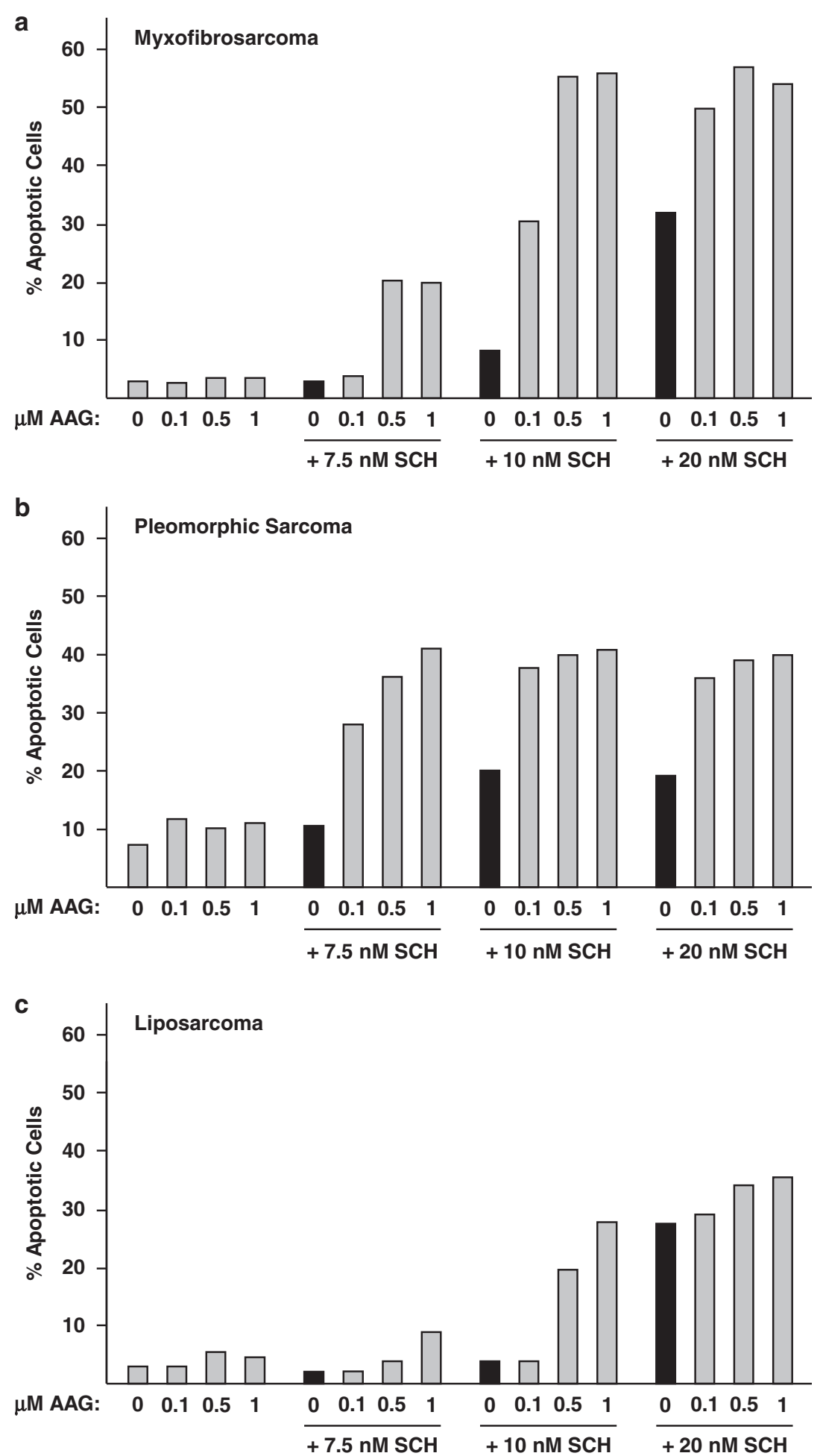

Figure 7 Effects of SCH and AAG on the survival of additional sarcoma cell cultures. (a-c). Cells received the indicated concentrations of SCH and AAG for $40 \mathrm{~h}$. Percent apoptotic cells was determined by FACS analysis of annexin V-stained cells

not. ${ }^{35}$ Similarly, Hsf-1-null transformed fibroblasts were more responsive to AAG than were their wild-type counterparts. ${ }^{36}$ Whether $\mathrm{SCH}$ prevents the upregulation of Hsp72 by Hsp90 inhibitors in OS cells remains to be determined.
Regardless of the mechanism, sequential application of $\mathrm{SCH}$ and AUY may allow flexibility when planning treatment schedules. Previous studies showed apoptosis of Rb-positive breast cancer cells sequentially exposed to AAG and taxol; 
AAG was effective when added to cells less than $4 \mathrm{~h}$ before or after taxol. ${ }^{37}$

Our studies show that Bax is predominantly cytosolic in OS cells receiving $\mathrm{SCH}$ or AUY but accumulates in the mitochondria of cotreated cells. How SCH and AUY collaboratively trigger the mitochondrial translocation of Bax is unclear at present. Of interest is a recent study showing the interaction of Bax with the Hsp90 cochaperone p23 in the cytosol of healthy cells. ${ }^{38}$ Depletion or overexpression of p23 did not affect the subcellular location of Bax, thus suggesting that p23 controls functions of Bax unrelated to its location in the cell or that it modulates Bax location in concert with additional events.

In addition to inducing apoptosis, $\mathrm{SCH}$ and AUY also affected cell cycle progression. Alone or together, they blocked OS cells in G0/G1, S and G2/M. As robust apoptosis requires both inhibitors, cell cycle arrest is unrelated to or insufficient for the apoptosis of OS cells. Similar to our findings on OS cells, CDK inhibitors reduced the percentage of BrdUpositive $S$ phase cells in myeloma, neuroblastoma, and colon, lung and breast carcinoma cultures; G2/M arrest, and in some instances G0/G1 arrest, was also observed. ${ }^{39-43}$ Hsp90 inhibitors arrest different tumor cell lines in different parts of the cell cycle: G0/G1 or G2/M, as shown by propidium iodide staining in several studies, ${ }^{28,}{ }^{44-48}$ or G0/G1, G2 or M, as shown by Lyman et al. ${ }^{49}$ by combined use of a thymidine analog and cell cycle markers. As an exception, HCT116 colon carcinoma cells did not accumulate in either G0/G1 or G1/M in response to $A A G .{ }^{46}$ Thus, the cell cycle responses of tumor cells to Hsp90 inhibitors are variable and may reflect cellular genotype, at least in part.

Advances in surgical techniques and the advent of multiagent chemotherapy have greatly improved the prognosis of OS patients. However, better treatments are still needed, particularly for patients with recurrent or metastatic disease. We suggest that $\mathrm{SCH}$ and AUY may be a promising strategy for treatment of OS and other types of sarcomas.

\section{Materials and Methods}

Cell culture. Fresh, finely minced sarcoma tissue was incubated with DNase I and collagenase $\mathrm{D}$ for $30 \mathrm{~min}$ at $37^{\circ} \mathrm{C}$, washed extensively and transferred to $10 \mathrm{~cm}^{2}$ culture flasks. Cells were incubated in a 1:1 mixture of Ham's F12 medium and Dulbecco's Modified Eagle's medium containing 10\% fetal calf serum. After expansion of cultures, frozen stocks were prepared. Frozen stocks served as the source of the OS cultures used in experiments. OS cells were passaged less than 20 times. NHOst cultures were purchased from Lonza (Walkersville, MD, USA) and cultured in Osteoblast Growth Medium (OBM Bullet Kit, Lonza). hFOB1.19 cells (normal human fetal osteoblasts expressing temperature-sensitive SV40 large T antigen) were obtained from ATCC and cultured at the permissive temperature $\left(33.5^{\circ} \mathrm{C}\right)$ in a $1: 1$ mixture of Ham's F12 medium and Dulbecco's Modified Eagle's medium containing $0.3 \mathrm{mg} / \mathrm{ml} \mathrm{G} 418$ and $10 \%$ fetal calf serum but lacking phenol red. WI38 cells (normal human fibroblasts) were from our frozen stocks and were cultured in minimum essential medium containing $10 \%$ fetal calf serum.

RT-PCR. Total cellular RNA was isolated using TRlzol reagent and used as a template for CDNA synthesis using the SuperScript First Strand Synthesis System (Invitrogen, San Diego CA USA). Primer sequences for alkaline phosphatase were: $5^{\prime}-$ ACGTGGCTAAGAATGTCATC- $3^{\prime}$ and $5^{\prime}-$ CTGGTAGGCGATGTCCTT A- $3^{\prime}$. Primer sequences for osteopontin were: $5^{\prime}-$ CCAAGTAAGTCCAACGAAA G- $3^{\prime}$ and $5^{\prime}-$ GGTGATGTCCTCGTCTGTA-3'. Primer sequences for osteocalcin were: 5'-ATGAGAGCCCTCACACTCCTC-3' and 5'-GCCGTAGAAGCGCCGA TAGGC-3'. Primer sequences for GAPDH were: 5'-ACCCAGAAGACTGTG GATGG-3' and 5'-TCTAGACGGCAGGTCAGGTC-3'. PCR products were run on $2 \%$ agarose gels and visualized by ethidium bromide staining
Annexin V binding. Cells were detached from plates with trypsin-EDTA and combined with floating cells. Cells were stained with Annexin V-FITC and PI/7AAD (BD Pharmingen, San Diego, CA, USA) and analyzed by FACS as described previously. ${ }^{50}$ Results shown in bar graphs were taken from the lower right quadrant of the plots and represent early apoptosis.

Western blotting. Cells were washed with ice-cold phosphate-buffered saline (PBS), scraped into PBS and collected by centrifugation. Pellets were resuspended in a lysis buffer containing $50 \mathrm{~mm}$ Hepes, $150 \mathrm{~mm} \mathrm{NaCl}, 1 \mathrm{~mm}$ EDTA, $1 \mathrm{~mm}$ EGTA, 10\% glycerol, $0.5 \%$ Nonidet P-40, 0.5\% Tween-20, 1 mm dithiothreitol, and protease inhibitor cocktail (Sigma, St Louis, MO, USA) and vortexed for $20 \mathrm{~min}$ at $4{ }^{\circ} \mathrm{C}$; insoluble material was removed by centrifugation. Proteins were resolved by SDS-polyacrylamide gel electrophoresis and transferred to nitrocellulose membranes. Membranes were incubated sequentially in Tris-buffered saline containing $0.05 \%$ Tween-20 and $5 \%$ non-fat dry milk as follows: no addition, $1 \mathrm{~h}$ at room temperature (blocking); primary antibody, overnight at $4{ }^{\circ} \mathrm{C}$; and secondary antibody, $1 \mathrm{~h}$ at room temperature. Bound secondary antibody was detected using WestPico and WestFemto chemiluminescent substrates (Pierce, Rockford, IL, USA).

Immunostaining. Cells on glass chamber slides received $40 \mathrm{~nm}$ MitoTracker Red (Invitrogen) $30 \mathrm{~min}$ before harvest. Cells were washed with PBS, fixed for $20 \mathrm{~min}$ in PBS containing $4 \%$ paraformaldehyde and permeabilized for $5 \mathrm{~min}$ in PBS containing $0.1 \%$ Triton $X-100$. Fixed, permeabilized cells were blocked with $1 \%$ bovine serum albumin and incubated with anti-Bax mouse monoclonal antibody (6A7, Santa Cruz, CA, USA) for $2 \mathrm{~h}$ at $37^{\circ} \mathrm{C}$. Cells were washed with PBS and incubated with goat anti-mouse IgG conjugated to Alexa Fluor-488 for $30 \mathrm{~min}$ at $37^{\circ} \mathrm{C}$. Stained slides were mounted with Vectashield mounting medium containing DAPI (Vector Laboratories, Burlingame, CA, USA). Fluorescent images were visualized by confocal microscopy.

Propidium iodide staining. Cells were removed from the plates with $0.125 \%$ trypsin and $0.5 \mathrm{~mm}$ EDTA in PBS; an equal volume of medium containing $10 \%$ serum was added to neutralize the trypsin. Cells were pelleted and resuspended in PBS $(1 \mathrm{ml})$, and $100 \%$ ethanol $(3.5 \mathrm{ml})$ was added slowly. Cells were incubated at $4{ }^{\circ} \mathrm{C}$ for a minimum of $16 \mathrm{~h}$, pelleted, and resuspended in PBS containing $0.1 \%$ Tween- $20,0.05 \%$ bovine serum albumin, $10 \mathrm{mg} / \mathrm{ml}$ RNase $A$ and $50 \mathrm{mg} / \mathrm{ml}$ propidium iodide. After a further incubation at $4{ }^{\circ} \mathrm{C}$ for at least $4 \mathrm{~h}$, cell cycle distribution was determined by FACS. DNA content (FL3: FL4 area) and relative amount of BrdU per cell (FL1:H Anti-BrdU-FITC) are plotted on the $x$ and $y$ axes, respectively, of the scatter plots.

BrdU staining. Cells received $30 \mu \mathrm{m}$ BrdU for times indicated in the figure legends. Cells were removed from the plates and fixed in PBS and ethanol as described above for propidium iodide staining. Pelleted cells were resuspended in $2 \mathrm{~N} \mathrm{HCl}$ and incubated for $30 \mathrm{~min}$ at $37^{\circ} \mathrm{C}$ to denature DNA. Sodium borate (final concentration, $0.1 \mathrm{~m}$ ) was added to neutralize the $\mathrm{pH}$, and cells were washed thoroughly to remove any residual acid. Cells were incubated overnight at $4{ }^{\circ} \mathrm{C}$ in PBS containing $0.1 \%$ bovine serum albumin, $0.1 \%$ Tween- 20 and a $1 / 20$ dilution of mouse monoclonal anti-BrdU-FITC antibody (eBioscience, San Diego, CA, USA). After washing, cells were incubated in PBS containing $0.1 \%$ Tween-20, $0.05 \%$ bovine serum albumin, $10 \mathrm{mg} / \mathrm{ml}$ RNase $A$ and $50 \mathrm{mg} / \mathrm{ml}$ propidium iodide staining for at least $4 \mathrm{~h}$ at $4{ }^{\circ} \mathrm{C}$. Percent BrdU-labeled cells and DNA content were determined by FACS.

Reagents. Antibodies to PARP, caspase-3, AKT, pAKT and pERK were obtained from Cell Signaling Technology (Beverly, MA, USA). Antibody to actin was obtained from Sigma. AAG and DMAG were purchased from LC Laboratories (Woburn, MA, USA) and InvivoGen (San Diego, CA, USA), respectively. AUY and HSP99 were provided by Novartis (East Hanover, NJ, USA), and SCH was provided by Merck/Schering-Plough Corporation (North Wales, PA, USA) and CTEP.

Statistical analysis. $P$-values were determined by a paired, two-tailed Student's $t$-test of three or more samples. Treated groups were compared with untreated (control) groups. $P$-values $<0.05$ are considered significant.

\section{Conflict of Interest}

The authors declare no conflict of interest. 
Acknowledgements. We acknowledge the helpful assistance of the Flow Cytometry Core and the Analytic Microscopy Core at the Moffitt Cancer Center. We thank Nancy Olashaw for manuscript preparation and Joseph J Johnson for his help in generating the confocal images.

1. Sakamoto A, Iwamoto Y. Current status and perspectives regarding the treatment of osteosarcoma: chemotherapy. Rev Recent Clin Trials 2008; 3: 228-231.

2. Allison DC, Carney SC, Ahlmann ER, Hendifar A, Chawla S, Fedenko A et al. A meta-analysis of osteosarcoma outcomes in the modern medical era. Sarcoma 2012; 2012: 704872.

3. Tan ML, Choong PF, Dass CR. Osteosarcoma: conventional treatment versus gene therapy. Cancer Biol Ther 2009; 8: 106-117.

4. Fu W, Ma L, Wang X, Bui MM, Gemmer J, Altiok S et al. The cyclin-dependent kinase inhibitor SCH727965 (dinaciclib) induces the apoptosis of osteosarcoma cells. Mol Cancer Ther 2011; 10: 1018-1027.

5. Parry D, Guzi T, Shanahan F, Davis N, Prabhavalkar D, Wiswell D et al. Dinaciclib (SCH 727965), a novel and potent cyclin-dependent kinase inhibitor. Mol Cancer Ther 2010; 9 : 2344-2353.

6. Contreras-Vallejos E, Utreras E, Gonzalez-Billault C. Going out of the brain: non-nervous system physiological and pathological functions of Cdk5. Cell Signal 2012; 24: 44-52.

7. Taipale M, Jarosz DF, Lindquist S. HSP90 at the hub of protein homeostasis: emerging mechanistic insights. Nat Rev Mol Cell Biol 2010; 11: 515-528.

8. Whitesell L, Lindquist SL. HSP90 and the chaperoning of cancer. Nat Rev Cancer 2005; 5 : 761-772.

9. Picard D. A stress protein interface of innate immunity. EMBO Rep 2008; 9: 1193-1195.

10. Maloney A, Clarke PA, Workman $P$. Genes and proteins governing the cellular sensitivity to HSP90 inhibitors: a mechanistic perspective. Curr Cancer Drug Targets 2003; 3: 331-341.

11. Schnur RC, Corman ML, Gallaschun RJ, Cooper BA, Dee MF, Doty JL et al. Inhibition of the oncogene product $\mathrm{p} 185 \mathrm{erbB}-2$ in vitro and in vivo by geldanamycin and dihydrogeldanamycin derivatives. J Med Chem 1995; 38: 3806-3812.

12. Egorin MJ, Lagattuta TF, Hamburger DR, Covey JM, White KD, Musser SM et al. Pharmacokinetics, tissue distribution, and metabolism of (dimethylaminoethylamino)17-demethoxygeldanamycin (NSC 707545) in CD2F1 mice and Fischer 344 rats. Cancer Chemother Pharmacol 2002; 49: 7-19.

13. Khong T, Spencer A. Targeting HSP 90 induces apoptosis and inhibits critical survival and proliferation pathways in multiple myeloma. Mol Cancer Ther 2011; 10: 1909-1917.

14. Brough PA, Aherne W, Barril X, Borgognoni J, Boxall K, Cansfield JE et al. 4,5-diarylisoxazole Hsp90 chaperone inhibitors: potential therapeutic agents for the treatment of cancer. J Med Chem 2008; 51: 196-218.

15. Kamal A, Thao L, Sensintaffar J, Zhang L, Boehm MF, Fritz LC et al. A high-affinity conformation of Hsp90 confers tumour selectivity on Hsp90 inhibitors. Nature 2003; 425: 407-410.

16. Holzbeierlein JM, Windsperger A, Vielhauer G. Hsp90: a drug target? Curr Oncol Rep 2010; 12: 95-101.

17. Porter JR, Fritz CC, Depew KM. Discovery and development of Hsp90 inhibitors: a promising pathway for cancer therapy. Curr Opin Chem Biol 2010; 14: 412-420.

18. Fadok VA, Voelker DR, Campbell PA, Cohen JJ, Bratton DL, Henson PM. Exposure of phosphatidylserine on the surface of apoptotic lymphocytes triggers specific recognition and removal by macrophages. J Immunol 1992; 148: 2207-2216.

19. Zong W, Thompson CB. Necrotic death as a cell fate. Genes Dev 2006; 20: 1-15.

20. Chang HY, Yang X. Proteases for cell suicide: functions and regulation of caspases. Microbiol Mol Biol Rev 2000; 64: 821-846.

21. Adams JM, Cory S. The Bcl-2 apoptotic switch in cancer development and therapy. Oncogene 2007; 26: 1324-1337.

22. Meijer L, Borgne A, Mulner O, Chong JP, Blow JJ, Inagaki $\mathrm{N}$ et al. Biochemical and cellular effects of roscovitine, a potent and selective inhibitor of the cyclin-dependent kinases cdc2, cdk2 and cdk5. Eur J Biochem 1997; 243: 527-536.

23. Wang D, de la Fuente C, Deng L, Wang L, Zilberman I, Eadie $C$ et al. Inhibition of human immunodeficiency virus type 1 transcription by chemical cyclin-dependent kinase inhibitors. J Virol 2001; 75: 7266-7279

24. Chao SH, Fujinaga K, Marion JE, Taube R, Sausville EA, Senderowicz AM et al. Flavopiridol inhibits P-TEFb and blocks HIV-1 replication. J Biol Chem 2000; 275: 28345-28348.

25. Senderowicz AM, Sausville EA. Preclinical and clinical development of cyclin-dependent kinase modulators. J Natl Cancer Inst 2000; 92: 376-387.

26. Toogood PL, Harvey PJ, Repine JT, Sheehan DJ, VanderWel SN, Zhou H et al. Discovery of a potent and selective inhibitor of cyclin-dependent kinase 4/6. J Med Chem 2005; 48: 2388-2406.

27. Stepanova L, Leng X, Parker SB, Harper JW. Mammalian p50Cdc37 is a protein kinase targeting subunit of Hsp90 that binds and stabilizes Cdk4. Genes Dev 1996; 10: 1491-1502.

28. Srethapakdi M, Liu F, Tavorath $\mathrm{R}$, Rosen $\mathrm{N}$. Inhibition of Hsp90 function by ansamycins causes retinoblastoma gene product-dependent G1 arrest. Cancer Res 2000; 60: 3940-3946.

29. Basso AD, Solit DB, Munster PN, Rosen N. Ansamycin antibiotics inhibit Akt activation and cyclin D expression in breast cancer cells that overexpress HER2. Oncogene 2002; 21: 1159-1166.
30. Rogakou EP, Pilch DR, Orr AH, Ivanova VS, Bonner WM. DNA double-stranded breaks induce histone H2AX phosphorylation on serine 139. J Biol Chem 1998; 273 5858-5868.

31. Gillet JP, Calcagno AM, Varma S, Davidson B, Bunkholt Elstrand M, Ganapathi R et al. Multidrug resistance-linked gene signature predicts overall survival of patients with primary ovarian serous carcinoma. Clin Cancer Res 2012; 18: 3197-3206.

32. Menezes DL, Taverna P, Jensen MR, Abrams T, Stuart D, Yu GK et al. The novel oral Hsp90 inhibitor NVP-HSP990 exhibits potent and broad-spectrum antitumor activities in vitro and in vivo. Mol Cancer Ther 2012; 11: 730-739.

33. Luo J, Solimini NL, Elledge SJ. Principles of cancer therapy: oncogene and non-oncogene addiction. Cell 2009; 136: 823-837.

34. Powers MV, Jones K, Barillari C, Westwood I, van Montfort RL, Workman P. Targeting HSP70: the second potentially druggable heat shock protein and molecular chaperone? Cell Cycle 2010; 9: 1542-1550.

35. Powers MV, Clarke PA, Workman P. Dual targeting of HSC70 and HSP72 inhibits HSP9O function and induces tumor-specific apoptosis. Cancer Cell 2008; 14: 250-262.

36. Bagatell R, Paine-Murrieta GD, Taylor CW, Pulcini EJ, Akinaga S, Benjamin IJ et al. Induction of a heat shock factor 1-dependent stress response alters the cytotoxic activity of hsp90-binding agents. Clin Cancer Res 2000; 6: 3312-3318.

37. Munster PN, Basso A, Solit D, Norton L, Rosen N. Modulation of Hsp90 function by ansamycins sensitizes breast cancer cells to chemotherapy-induced apoptosis in an RB and schedule-dependent manner. Clin Cancer Res 2001; 7: 2228-2236.

38. Vogel S, Raulf N, Bregenhorn S, Biniossek ML, Maurer U, Czabotar P et al. Cytosolic Bax: does it require binding proteins to keep its pro-apoptotic activity in check? J Biol Chem 2012; 287: 9112-9127.

39. Whittaker SR, Te Poele RH, Chan F, Linardopoulos S, Walton MI, Garrett MD et al. The cyclin-dependent kinase inhibitor seliciclib (R-roscovitine; CYC202) decreases the expression of mitotic control genes and prevents entry into mitosis. Cell Cycle 2007; 6: 3114-3131.

40. Zhang T, Jiang T, Zhang F, Li C, Zhou YA, Zhu YF et al. Involvement of p21 Waf1/Cip1 cleavage during roscovitine-induced apoptosis in non-small cell lung cancer cells. Oncol Rep 2010; 23: 239-245.

41. Jorda R, Havlicek L, McNae IW, Walkinshaw MD, Voller J, Sturc A et al. Pyrazolo [4,3-d]pyrimidine bioisostere of roscovitine: evaluation of a novel selective inhibitor of cyclin-dependent kinases with antiproliferative activity. J Med Chem 2011; 54 2980-2993.

42. Schutte B, Nieland L, van Engeland M, Henfling ME, Meijer L, Ramaekers FC. The effect of the cyclin-dependent kinase inhibitor olomucine on cell cycle kinetics. Exp Cell Res 1997 236: 4-15.

43. Wesierska-Gadek J, Borza A, Komina O, Maurer M. Impact of roscovitine, a selective CDK inhibitor, on cancer cells: bi-functionality increases its therapeutic potential. Acta Biochim Pol 2009; 56: 495-501.

44. Okamoto J, Mikami I, Tominaga Y, Kuchenbecker KM, Lin YC, Bravo DT et al. Inhibition of Hsp90 leads to cell cycle arrest and apoptosis in human malignant pleural mesothelioma. J Thorac Oncol 2008; 3: 1089-1095.

45. Garcia-Morales P, Carrasco-Garcia E, Ruiz-Rico P, Martinez-Mira R, Menendez-Gutierrez MP, Ferragut JA et al. Inhibition of Hsp90 function by ansamycins causes downregulation of cdc2 and cdc25c and G2/M arrest in glioblastoma cell lines. Oncogene 2007; 26 : 7185-7193.

46. Hostein I, Robertson D, DiStefano F, Workman P Clarke PA Inhibition of signa transduction by the Hsp90 inhibitor 17-allylamino-17-demethoxygeldanamycin results in cytostasis and apoptosis. Can Res 2001; 61: 4003-4009.

47. Lesko E, Gozdzik J, Kijowski J, Jenner B, Wiecha O, Majka M. HSP90 antagonist, geldanamycin, inhibits proliferation, induces apoptosis and blocks migration of rhabdomyosarcoma cells in vitro and seeding into bone marrow in vivo. Anticancer Drugs 2007: 18: 1173-1181.

48. Georgakis GV, Li Y, Younes A. The heat shock protein 90 inhibitor 17-AAG induces cell cycle arrest and apoptosis in mantle cell lymphoma cell lines by depleting cyclin D1, Akt, Bid and activating caspase 9. Br J Haematol 2006; 135: 68-71.

49. Lyman SK, Crawley SC, Gong R, Adamkewicz JI, McGrath G, Chew JY et al. High-content, high-throughput analysis of cell cycle perturbations induced by the HSP90 inhibitor XL888. PLoS One 2011; 6: e17692.

50. Fu W, Ma Q, Chen L, Li P, Zhang M, Ramamoorthy S et al. MDM2 acts downstream of p53 as an E3 ligase to promote FOXO ubiquitination and degradation. J Biol Chem 2009; 284 13987-14000.

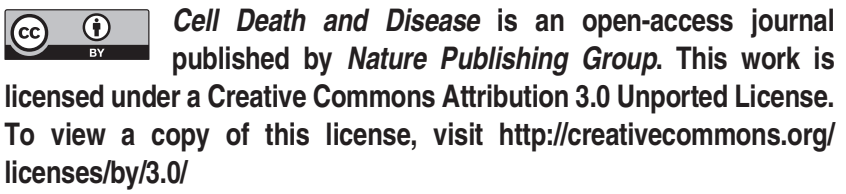

